\section{WEDDINGS AND THAI \\ WOMEN: THE \\ CONSTRUCTION OF \\ WEDDINGS AND THE \\ PORTRAYAL OF THAI \\ WOMEN THROUGH \\ WEDDING STORIES IN THAI \\ WEDDING MAGAZINES ${ }^{1}$}

\section{Permtip Buaphet $^{2}$}

\section{บทคัดย่อ}

นิตยสารแต่งงานไทยเป็นแหล่งการหาข้อมูลเบื้องต้น เกี่ยวกับการวางแผนการแต่งงานสำหรับหญิงไทย งานวิจัยนี้มีวัตถุประสงค์เพื่อวิเคราะห์การประกอบ สร้างงานแต่งงานและการนำเสนอภาพเจ้าสาวใน บริบทของนิตยสารแต่งงานไทยโดยใช้วิธีการ วิเคราะห์ตัวบทและภาพ งานวิจัยนี้มุ่งค้นหาความจริง เกี่ยวกับข้อตกลงภายในสังคมและอุดมการณ์ที่ เกี่ยวข้องกับการแต่งงานซึ่งปรากฏในนิตยสารแต่งงาน

\footnotetext{
1 (งานแต่งงานและผู้หญิงไทย: การประกอบสร้างงานแต่งงานและการนำสนอภาพ ของผู้หญิงไทยผ่านรื่องเล่าการแต่งงานในนิตยสารแต่งงานไทย) This study was supported by a research grant from the Ratchadaphiseksomphot Endowment Fund, Chulalongkorn University. I am especially grateful to Assoc. Prof. Dr. Suchitra Chongstivatana, Director of the Thai Studies Institute, Chulalongkorn University for her immeasurable support.

2 (เพิ่มทิพย์ บัวเพ็ชร์) Lecturer, Thai Civilization Division, Chulalongkorn University, Thailand. E-mail: permtip.b@chula.ac.th.
}

ไทย งานวิจัยเรื่องนี้เก็บข้อมูลจากนิตยสารแต่งงาน ไทย 3 หัวเรื่อง ประกอบด้วย Wedding Guru, We, และ Love Wedding Magazine มีจำนวนทั้งสิ้น 22 ฉบับ และ 132 เรื่อง ตั้งแต่เดือนพฤศจิกายน 2557 ถึงเดือน ตุลาคม 2558 นิตยสารเหล่านี้มีกลุ่มผู้อ่านเป็นผู้หญิง อายุตั้งแต่ 20 ปีขึ้นไป ผลการศึกษาแสดงให้เห็นถึง วิธีการกำหนดความหมายของงานแต่งงานและ บทบาทของนิตยสารแต่งงานไทยในการส่งผ่าน ความคิดบางประการเกี่ยวกับงานแต่งงานอันพึง ปรารถนาในสังคมไทย เช่นเดียวกับการตอกย้ำ ความคิดเรื่ององค์ประกอบของชีวิตในอุดมคติสำหรับ ผู้หญิง ผลการศึกษาในด้านเนื้อหาของนิตยสาร ชี้ให้เห็นว่างานแต่งงานและผู้หญิงที่เป็นเจ้าสาวใน นิตยสารแต่งงานไทยถูกสร้างในทางบวกหรือแง่ดี เพียงเท่านั้น กล่าวคืองานแต่งงานและการเป็นเจ้าสาว ถูกให้ความหมายในฐานะการเป็นแบบอย่างของการมี ชีวิตในอุดมคติ

\begin{abstract}
Thai wedding magazines have been a primary resource for Thai women seeking wedding planning information. This study analyses the construction of weddings and investigates the portrayal of brides within the context of Thai wedding magazines by combining textual analysis and visual research methods. It investigates the social arrangements indicated in these magazines and the associated wedding ideology represented. Data for analysis is based on three magazines (Wedding Guru, We, and Love Wedding Magazine). There were twenty-two magazine issues and one
\end{abstract}


hundred and thirty-two stories in total, covering the period from November 2014 October 2015. These magazines are targeted at women in their 20s and older. The study reveals how Thai wedding magazines formulate the meaning of weddings and the role of Thai wedding magazines in the transmission of particular ideas about desirable weddings in Thai society, while also reinforcing notions of what constitutes the ideal life for women. Findings in terms of the content indicate that weddings and women as brides in Thai wedding magazines are constructed only in positive ways. That is to say, weddings and the act of becoming a bride are constructed as examples of an already achieved 'ideal' life.

\section{Introduction}

Over 300,000 marriages occur annually in Thailand. Around 80 to 90 per cent of married couples wed in ceremonies, generating an estimated 30 billion baht (approximately US $\$ 857,000,000$ ) for the wedding industry. The cost of the average wedding has exceeded 500,000 baht for each couple (US $\$ 14,000$ ) in the past five years ${ }^{3}$. This indicates that couples consider wedding ceremonies to be a very important life event. More broadly, weddings are beneficial to the economy. As wedding costs have increased by an average of 5 per cent per year over the past 15 years (Daniels and Loveless, 2007: 4), a significant number of couples spend a considerable amount of money on their weddings. Many couples opt for lavish themed ceremonies because they want to

\footnotetext{
${ }^{3}$ http://www.jr-rsu.net/article/1673, accessed $1 / 20 / 2016$.
}

experience a sense of magic in their lives (Otnes and Pleck, 2003: 12).

'Wedding' is defined by The Oxford English Dictionary as "a marriage ceremony" (Soanes, 2010: 869). Wedding is thus associated with marriage. 'Marriage' is defined as "the formal union of a man and a woman, by which they are or become husband and wife" (Soanes, 2010: 461), while The Dictionary of Feminist Theory defines marriage as "the institution which traditionally provides women with a social identity" (Humm, 1995: 159). To be more specific, 'wedding' emphasizes the ceremony whereas 'marriage' is more likely to be used to highlight the relationship and status of couples or the institution in society. In this sense, wedding and marriage are important to women's lives since they provide a sense of belonging within their society and help to improve their selfesteem.

Although marriage is universal, there is no single internationally approved pattern since weddings feature differently across cultures. Traditionally, the family of the groom was responsible for paying for the wedding in Thailand, and this still seems to be the case in contemporary Thai society. Spending large amounts of money on lavish wedding receptions has been a common point of critique, based on the notion that the marriage itself should be considered the more significant part of a union. On one hand, this results from consumerism, which advocates that excessive purchasing is beneficial to the economy. On the other hand, the media, especially magazines, has framed specific ideas that dominate readers' perceptions of the meaning of weddings as 
well as the ideal type of ceremony. With the impact of post-structuralist writing, feminist scholarship on women's magazines moved beyond the question of ideology. As McRobbie (1997: 193) writes, "instead of seeking to uncover the truth behind ideology, the question now was to consider the power of meaning".

The question of the construction of weddings and the portrayal of Thai women through wedding stories in Thai wedding magazines is the subject of my study. The two research questions are as follows: 1 . What is a 'wedding' and how is it presented in Thai wedding magazines? 2. How are women displayed in Thai wedding magazines?

Investigating wedding stories by and about actual women who are not celebrities or actresses enables a better understanding of how the structure and meanings of weddings and ordinary women's lives are constructed in these contexts. I became curious about these stories and whether they actually represented 'ordinary' women's lives or were just what was considered 'normal' by the magazines.

In research on women's magazines dating back to 1992, Friedan explained the way in which women's magazines conveyed ideas of femininity to readers by reproducing the concept of the 'happy housewife heroine'. This allegory of the 'happy housewife' became a prominent feature of the discourse of femininity during the 1950s - 1960s. Winship (1987: 18) also suggested that this construction of womanhood in women's magazines should be rejected and reconsidered: "Many of the guises of femininity in women's magazines contribute to the secondary status from which we still desire to free ourselves. At the same time it is the dress of femininity which is both a source of the pleasure of being a woman [...] and in part the raw material for a feminist vision of the future" (Winship, 1987: xiii). Both Friedan's (1992) and Winship's (1987) works focused on the 1950s, 1960s, and 1980s, respectively. There is therefore a question of the extent to which this old-fashioned gendered image remains relevant in the $2010 \mathrm{~s}$.

Opposite-sex unions are the focus of this study; same-sex couples are not included. The purpose of the study is to define the cultural meanings inherent in the concept of weddings in Thai society. The presentation of weddings as part of marriage is common in Thai wedding magazines. Furthermore, an examination of the stereotypical notions of wedding receptions can reveal understanding of the mediated construction of weddings in Thai society.

In my study I focus on a particular type of media: Thai wedding magazines aimed at women who are in their early 20 s and older. The selection of non-celebrity couples and their weddings in Thai wedding magazines is an issue for debate since one might argue that these 'ordinary' weddings were constructed in a particular way in order to conform to cultural expectations. Such expectations are specific to a Thai cultural context since, as Guiren (2006: 237) states, "every society has its own distinct culture and concept of value shared by its people". These weddings may then be considered as 'normal' by the magazines rather than by the society. 


\section{Objectives and Scope of the Study}

This paper aims to examine the mediated construction of weddings and analyze the portrayal of women within the context of Thai wedding magazines. The data used in this study are three wedding magazines: $\underline{W e}$, Wedding Guru, and Love Wedding Magazine. These magazines were selected for three reasons: Firstly, the wedding magazines in my sample appeal to a particular readership since they are aimed at women in their 20s and older. Secondly, these magazines have never been analyzed in terms of the construction of weddings and women. This study thus brings a new understanding to the field of wedding magazines, and to the construction of women. Thirdly, magazines construct women in particular ways. This includes their portrayal in wedding columns. Moreover, little is said about this in the existing research to date.

I decided to focus on the period November 2014 - October 2015, i.e. a period of one year. I chose to collect issues from the magazines in question and examine each issue published during this period. This provided a clear and manageable timeframe for my data collection. Purposive sampling was used for choosing three particular periodical magazine issues: monthly, bimonthly, and trimonthly. We, a monthly magazine, pays particular attention to brides-to-be, as is indicated in the magazine's bi-line: 'A handbook for stylish weddings'. Wedding Guru similarly targets fashionable brides-to-be. This is

4 See http://www.we-mag.com, accessed $15 / 11 / 2015$. evidenced in its slogan: 'Imaginative wedding style'. 5 Love Wedding Magazine correspondingly focuses on future brides, shown by their use of the motto 'bride and wedding directory' on the front cover. By having 'wedding' in the title and 'bride' in its slogan, Love Wedding Magazine directly connects women to weddings.

The ordinary people's weddings that were investigated appeared in the following columns: 1. Real wedding and Wedding diary in $\underline{W e}, 2$. Real wedding and Wedding celebration in Wedding Guru, and 3. Real wedding in Love Wedding Magazine. It is noticeable that the columns of all three magazines share the phrase 'Real wedding' in their titles. By having 'real' in the column title, they draw on the notion of weddings as important and authentic. Since 'real', according to The Oxford Dictionary (2010: 624), is "used to emphasize the significance or seriousness of a situation".

\section{Definitions of Key Terms}

$A$ wedding: The term is defined here as a ceremony portrayed in a Thai wedding magazine where two heterosexual partners are united in marriage.

A woman: In this study, the term is interpreted as a female bride, regardless of age, who is presented in a wedding story.

Thai wedding magazines: The term specifically refers to We, Wedding Guru, and Love Wedding Magazines published

\footnotetext{
${ }^{5}$ See http://www.honeymoontravel.co.th/ weddingguru/WD-07/index.php, accessed $15 / 11 / 2015$
} 
from November 2014 - October 2015.

A wedding story: In this study this refers to the story narrated by an editor about a wedding in the selected Thai wedding magazines.

Mediated construction: The term, in this study, is transliterated as a presentation that has gone through various stages of correction on the structure of wedding stories in relation to content and images by Thai wedding magazines.

\section{Background of the Study}

Based on the actual wedding stories that those magazines contained I selected wedding stories that were narrated by columnists and/or editors. One of the distinct indicators of these wedding stories is that a writer's name appeared in the story. An obvious instance is 'A Night Fairy Tale, Text: Duenpongo, Bride \& Groom - Groom: Mr. Saksiri Lerdbanluechai, Bride: Mrs. Pinnapa Wongruengwisan' (Wedding Guru, MarchApril 2015, p. 46). Having the editor's name before the bride's and groom's names at the beginning of a story implies the significance of the editor, both in terms of contributing to the story and in framing particular ideas through the story.

I did not use stories that were told by couples themselves since analyzing the language used by the editors of a text can reveal a certain presented ideology and the mediated construction of weddings embedded in wedding stories.

The principal approaches I use in my research are content analysis, discourse analysis, and visual methodologies. The content analysis approach was applied to draw out categories from my data. It included frequency counts of the occurrences of wedding concepts represented by words. I made lists of wedding stories and classified them under meta-themes in order to do further thematic analysis. My theme selection was guided by my data and the dominant titles used. I assigned narratives to these themes through scrutinizing their titles and content. In trying to explore this specific ideological framework, I applied discourse analysis in my subsequent analysis, focusing on mediated language as used in the stories. I focused on the vocabulary used to convey ideas of weddings and womanhood in each text. Such vocabulary is a significant component in framing thought since it can shape users' ideas and beliefs, particularly when the same groups of words are used repeatedly.

In order to analyze the photos presented as part of the stories, I employed visual methodologies to interpret the meanings of wedding and brides' photos regarding 'cultural significance', 'social practices', and 'power relations'. These sources directed my approach to reading the images in my sample. Visual methodologies were used to interpret the meanings of images in wedding stories. An interest was to explore both representational and nonrepresentational aspects of images in Thai wedding magazines. To interpret visual images, according to Rose (2014: 19), it is necessary to consider three sites at which the meanings of an image are made: "1. the site(s) of the production of an image, 
2. the site of the image itself, and 3. the site(s) where it is seen by various audiences". These three sites were investigated because they contribute to a critical understanding of the mediated construction of images in Thai wedding magazines. The visual figures examined in my study lead to explanations of the portrayal of weddings and women in the narratives. A photograph's structure, according to Barthes (1987: 149), has to be considered in association with the surrounding language and the text such as caption, headline and layout. Photographic analysis was thus a tool for exploring the messages the stories were constructed to convey.

In my study, I have drawn on the intersection of two interdisciplinary academic subjects: women's studies and cultural studies. To investigate the construction of women in the magazines used, it is necessary to understand the specificities of Thai cultural contexts in relation to the way women are depicted in women's magazines.

In her doctoral dissertation, Thainess and Bridal Perfection in Thai Wedding Magazines, Skulsuthavong (2016: iii) examined images of brides and wedding preparation narratives in order to gain an insight into how standards for bridal perfection are constructed for Thai bridesto-be. She found that Thai wedding magazines emphasize the discipline to maintain beauty and good behavior as a wife. The magazines only represent the images of beautiful brides with cultural expectations and control.
When it comes to discussing femininity, Angsuviriya (2008: vii) stated that women's magazines reflect three notions of femininity: 1 . aesthetic physical beauty and dress, 2. behavior across gender and emotional expressions, and 3. duties and responsibilities in housework and work outside the home. The magazines create a conception of femininity to support men - a clear indication of the dominant patriarchal ideology.

The Dictionary of Feminist Theory defines 'femininity' as 'a term which describes the construction of "femaleness" by society and which connotes sexual attractiveness to men' (Humm, 1995: 93). Traditionally, in Thailand, women, as Vichit-Vadakan claimed (1994: 516), were expected to be 'good' wives, mothers, and homemakers. They were economically dependent on men and had to be solely responsible for household chores. This underlines the inferiority of women to men, their dependency both economically and emotionally. However, images of women in contemporary Thai wedding magazines may be different from the past because the meanings of being a woman have changed over time. The reconstitution of femininity in contemporary Thailand thus involves the interplay of modern choices and social expectations.

Culture, according to Anderson (2006: 46), is "a pattern of expectations about what are appropriate behaviors and beliefs for the members of a society". Culture includes the norms, values and beliefs of a society. By drawing cultural studies into my work, the depiction of women in relation to their weddings in Thai wedding magazines will 
be explained in terms of cultural values. Cultural values are considered to inform the judgment of appropriate behavior (Rokeach, 1971: 23). Cultural values, in this sense, define what kinds of topics and photos are appropriate to display in public. This is also the case in Thai wedding magazines where columnists and editors mediate the construction of weddings by arranging the content and photos. They take readers' photos, then select and construct the order of events creating the meaning of the story. This construction is highlighted through the fact that both columnists' and photographers' names appear in each column in the magazine as I shall illustrate in the next section: The construction of wedding stories in wedding magazines.

\section{The Construction of Wedding Stories in Thai Wedding Magazines}

Wedding stories in my sample generally consist of three parts: introduction, body, and ending. The introduction is the first section in wedding stories. It is composed of headings or the main titles of the stories, which include couple's names, date and place of their wedding ceremonies, usually in large colorful letters designed to draw the readers' attention. This is evidenced by the large font size, which dominates the introduction. It is commonly followed by the body and ending.

In my sample, the introduction primarily contains two or more typical subsections: title, couple's names, date and place of wedding ceremony. For example, 'Heavenly Garden - Dr. Kwanpeemai Panorchan (Kwan) and Dr. Chatchapol Kaitkajorntada (Aew), Sunday $27^{\text {th }}$ August
2014, Grand Hall, Plaza Athénée Bangkok, A Royal Méridien Hotel' ( $\underline{W e}$, January 2015, p. 40). By using 'garden' in the title, the author implies the couple's wedding theme from the beginning. Readers thus can predict that the theme of the wedding reception will be based on beautiful gardens. Alternatively, the introduction provides personal details about the bride and groom under the title. In this case date and place of wedding are excluded. An example is 'Absolutely Love: Bride \& Groom - Groom: Khun ${ }^{6}$ Pum - Pamonkon Chayavijitsin, a graduate from Oregon State University in Finance, Business Administration, and International Economics. An owner of Chaydon Sathorn Hotel and a managing director of Meko Clinic. Bride: Khun Mew-Wararat Sirikootta, a beautiful doctor, a graduate from the Faculty of Medicine Siriraj Hospital. She is pursuing a dermatology postgraduate degree at Siriraj Hospital' (Wedding Guru, November - December 2014, p. 100). When the bride and groom's personal details are discussed instead of wedding setting, by convention the introduction commonly includes their education and career. It is noticeable that only positive attributes of wedding couples are mentioned in the introduction as well as in other sections of the story as I shall explain later.

It is apparent that unpleasant aspects of wedding couples, such as lack of education or unemployment, are not shown in the introduction. To put it another way, the

\footnotetext{
${ }^{6}$ Khun is a common polite pronoun for Thai people and a title equivalent to Mr., Miss., and Mrs.
} 
introduction is about promoting newly married couples. Keeping the concept of the introduction the same, different magazine issues have different styles to introduce brides and grooms. The introduction of Love Wedding Magazine, for instance, consists of non-personal information such as the names of wedding planners and photographers. To give an example: 'the wedding of Patcharawadee Weerabawornpong (Gift) and Wanlob Kamonwisit (Mark)@The Berkeley Hotel Pratunam, Flower design and decoration: Rainforest Wedding, Tel: 080-558-8880, Photo: Narakorn Photography, Wedding Theme: Dream comes true' (Love Wedding Magazine, February - April 2015, p. 116).

Generally, additional information aims to advertise wedding businesses such as wedding photographers, wedding planners, and wedding florists. This is evidenced by the telephone numbers, which will allow readers to contact them if they are interested. To be more specific, details in the introduction section not only provide a short biography of brides and grooms but also promote wedding companies.

The next significant component in the introduction is a story title. There are two types of story titles in the wedding magazines in my sample: story titles with sub-story titles and story titles without substory titles. In magazine issues that set themes for wedding stories, story titles usually include sub-story titles. Each substory title links to the main story title. An explicit example is the wedding celebration column in Wedding Guru. The magazine began its story title as 'Every Route is filled with Love'. Then came four sub- story titles as follows: 1. 'Love All of You - Mr. Wanlop Kamonvisit and Miss Patcharawadee Weerabavornpong' (Wedding Guru, March - April, p. 42), 2. 'A Night of Fairytales - Mr. Saksiri Lertbanluechai and Miss Pinnapa Wongruengwisarn' (Wedding Guru, March - April, p. 46), 3. 'You Complete Me - Mr. A Ratchameth Chaipichayarat and Miss Oil Aimpawee Sirawatthanasit' (Wedding Guru, March - April, p. 50), 4. 'Destiny of Love - Mr. Jirapat Watanawekin and Miss Pantira Lekeakarat' (Wedding Guru, March - April, p. 54). Altogether the sub-titles I analyze are representative of the 'love' that featured commonly in the wedding magazines I examined. The sub-story titles here connect the ideas of weddings to affection, romance, and fulfillment by using the words: 'love', 'fairy', and 'complete' respectively. The magazines concentrated on certain positive aspects and the meanings of weddings, using story titles that occasionally revealed wedding themes.

When it comes to discussing details of wedding receptions, the next part will serve to capture the readers' attention - the body of the story. Typically, the body of the story is the longest section. It basically provides details of the wedding reception. Many wedding stories in my sample were accompanied by pre-wedding photos, entrance of the reception, backdrop and gallery, stages, cards, gifts, wedding gowns and suits, after-party dresses, makeup and hair artists, and fashion guides for guests. Prominently, these weddings were held in luxurious hotels in Bangkok. In the past, however, wedding celebrations in Thailand were often conducted at brides' homes. The 
choice of wedding venues was determined mainly by the family's economic status. Wedding celebrations in Thai wedding magazines were thus linked to couples' economic and social position. Although participating in a mass or collective wedding $^{7}$ is highly anti-consumptive, and helps couples that cannot afford to hold lavish weddings, it is noticeable that a mass or collective wedding was not mentioned at all in Thai wedding magazines I analysed. This signifies the mediated construction of weddings that includes high social and economic status. Furthermore, these social and economic issues have an influence on the construction of weddings and the portrayal of women in the magazines as I shall explain later.

Following on from the content section is the ending. The endings of the wedding stories vary depending on their themes. There are three common endings in Thai wedding magazines: 1 . tips and suggestions from couples, 2. further information, and 3. advertising wedding businesses. Tips and suggestions from couples guide readers in how to conduct their wedding ceremonies successfully. At the end of the story about a woman who just had her $4^{\text {th }}$ wedding anniversary celebration, for example, the recommendation to readers read:

'First of all, you must have a clear objective. You should know why you want to have a wedding celebration. Then choose the best

\footnotetext{
${ }^{7}$ A mass or collective wedding ceremony is a wedding ceremony in which many couples are getting married at one time due to economic and social constraints.
}

\begin{abstract}
things for your wedding. In my opinion, wedding planners are the most important factor because they make brides and grooms feel less exhausted. They also can make everything perfect because they are professionals...' ( $\underline{\text { We }}$, April 2015, p. 58)
\end{abstract}

The tips and suggestions above are a discussion of a woman's feelings about her wedding experience. The ending was directly linked to a woman's positive attitude towards her own wedding. In general, the endings were usually women's suggestions to readers. These endings were usually the last paragraph of each story.

Occasionally stories also ended with further information in the form of wedding guidelines for their guests. Providing wedding guidelines such as theme, venue, gimmicks and colors in the wedding magazines is a way to specialize women's weddings since these ideas are utilized differently for each wedding.

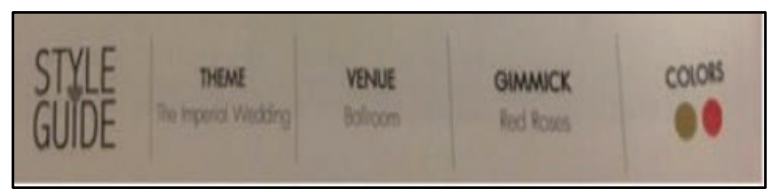

Image 1: Wedding guidelines for guests (We, April 2015, p. 58)

Source: author's photograph.

Unlike further information, advertising wedding businesses relevant to women's weddings, and providing contact numbers, highlights women's individuality in the sense that buying luxurious wedding dresses, hiring highly-skilled wedding planners, make-up artists and 
photographers, for instance, may not be possible for every couple. This kind of advertising is common in Thai wedding magazines as part of the ending as shown in Image 2.

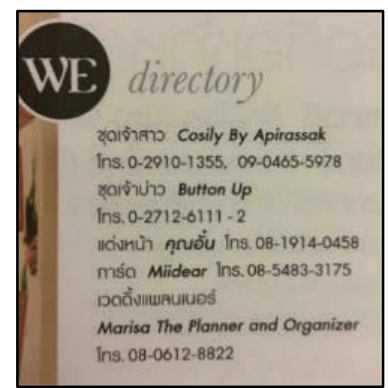

Image 2: Advertising wedding businesses (We, April 2015, p. 51)

Source: author's photograph.

Advertising wedding businesses as displayed in Image 2 consists of several businesses such as wedding dress rentals, bridal make-up specialists, wedding invitation cards and a wedding planner company. It is noticeable that these businesses are displayed with their contact numbers. This not only promotes wedding businesses but also announces the couple's economic status.

Lastly, wedding stories in Thai wedding magazines involve features that follow particular formats, where readers are able to view 1. The bride's and groom's personal details as provided by the columnist 2. Types and details of wedding ceremonies and 3. Advertising of wedding services. These features reveal the content of wedding stories in Thai wedding magazines. Next, the meaning of weddings will be investigated in the following section.

\section{The Construction of Weddings in Thai Wedding Magazines}

Media is powerful in terms of framing and defining a situation (Tankard, 2001: 96). In the case of weddings, Thai wedding magazines manage to convey particular ideas and values to regular readers. More specifically, Thai wedding magazines recreate the meaning of weddings as well as the norms that should be followed in these weddings. Based on an analysis of the titles of the wedding stories used in this study, weddings were constructed only in positive ways by linking them to pleasant emotions and success in life.

When it comes to discussing positive feelings, weddings in Thai wedding magazines are associated with love, happiness, and fulfillment. In part, there is a connection between weddings and love. Weddings are constructed as symbolic expressions of love. For instance, there are stories titled 'Greatest Love of All' ( $\underline{W e}$, February 2015, p. 62), 'Promise of Love' ( $\underline{W e}$, April 2015, p. 50), 'When Love Meets, Happiness Begins' (Wedding Guru, January February 2015, p. 92). The titles in wedding stories, as an illustration, reflect how delightful the wedding days were, beginning from 'A Splash of Happiness' ( $\underline{W e}$, February 2015 , p. 66) to 'Heavenly Day' ( $\underline{W e}$, November 2014, p. 56). Using the words 'splash' in the title 'A Splash of Happiness', and 'heavenly' in 'Heavenly Day' suggests that the wedding day is special and different from ordinary days since it is a day full of happiness.

Correspondingly, fulfillment in weddings is presented as crucial since it leads to a 
perfect life. Examples include: 'Wishes Filled' ( $\underline{W e}$, January 2015, p. 44), 'Absolute Perfection' ( $\underline{W e}$, January 2015, p. 46), 'Filling Each Other with Love' ( $\underline{\text { We }}$, January 2015, p. 50). From these examples, the words used in the titles of wedding stories help to present weddings as a means of making life complete. Employing 'wish', 'perfection', and 'love' in the titles respectively, Thai wedding magazines highlight three important values and connect them to wedding receptions. To put it another way, weddings are constructed as a concrete display of love. Thus, weddings in Thai wedding magazines are presented as important for females since they are an expression of love from men. In other words, in Thai society, the wedding cost is a man's responsibility to his future wife.

According to the data obtained, there were stories that related weddings to the success of love. The following examples: 'The Seven Years of Love' ( $\underline{W e}$, February 2015, p. 60), 'Fight for Love' ( $\underline{\text { We}}$, March 2015, p. 44), and 'Journey of Love' (Wedding Guru, January - February 2015, p. 76) indicate that being successful in love takes time and the overcoming of obstacles. The ultimate success of love is presented in the form of weddings. Weddings in this sense signify the announcement and the celebration of the success of love for both grooms and brides.

On the whole, there were one hundred and thirty-two wedding stories in total in my sample which concentrated on love, success, fulfilment, and happiness as shown in Table 1.

Table 1 shows that the titles of wedding stories were linked to four meanings: love, success, fulfilment, and happiness. Weddings were more likely to be constructed as symbolic expressions of love in Thai wedding magazines. There were 68 out of 132 stories which focused on love. The meanings of weddings displayed in Thai wedding magazines as success, fulfillment, and happiness were less likely to be presented. There were twenty-eight, twenty, and sixteen wedding stories connected with success, fulfilment, and happiness respectively. This indicates the positive meanings associated with weddings in the public context of Thai wedding magazines.

When it comes to illustrating wedding norms, Thai wedding magazines construct weddings by inventing traditions to standardize weddings in Thai society. That is to say, invented traditions in weddings derive from applying western culture to Thai weddings. Four typically western wedding traditions framed by Thai wedding magazines are the diamond engagement ring, the double-ring ceremony, the white wedding gown, and the themes of wedding receptions, respectively. 
Table 1 indicates the meanings of topics related to weddings covered in Thai wedding magazines.

\begin{tabular}{|l|c|c|c|c|}
\hline \multirow{2}{*}{$\begin{array}{c}\text { The meanings of } \\
\text { weddings }\end{array}$} & \multicolumn{3}{|c|}{ Thai wedding magazine issues } & \multirow{2}{*}{ Total } \\
\cline { 2 - 4 } & We & $\begin{array}{c}\text { Wedding } \\
\text { Guru }\end{array}$ & $\begin{array}{c}\text { Love } \\
\text { Wedding } \\
\text { Magazine }\end{array}$ & \\
\hline 1. Love & 46 & 20 & 2 & 68 \\
\hline 2. Success & 18 & 2 & 8 & 28 \\
\hline 3. Fulfilment & 14 & 6 & - & 20 \\
\hline 4. Happiness & 10 & 4 & 2 & 16 \\
\hline Total & 88 & 32 & 12 & 132 \\
\hline
\end{tabular}

\section{The Diamond Engagement Ring}

Giving a diamond engagement ring is not part of traditional Thai wedding culture. In fact, the first reported diamond engagement ring, as claimed by Kunz (2011: 234-35), was given by the Emperor Maximilian to Mary of Burgundy in 1477. The word 'diamond' comes from the Greek word 'adámas', meaning 'adamant' or 'unbreakable' (Bain, 2011: 3). With its positive connotations, the diamond ring has thus represented long-lasting love for centuries. Together with the famous slogan from the De Beers 'A diamond is forever' campaign, this strongly influences brides-to-be (Barash, 2012: 9) and is possibly responsible for the tradition of wearing diamond engagement rings.

Moreover, the 'Two months' salary' tradition disseminated by De Beers, as stated by Daniels and Loveless (2007:
47), suggests a suitable price for the diamond engagement ring that a man should purchase for his future bride. Interestingly, before the Depression, diamond rings, as claimed by Kunz (2011: 230), were not an important component of engagement for most Americans. According to Brinig (1990: 205), the diamond engagement ring has been customary in the United States of America since the end of World War II.

In traditional Thai culture, a future groom would provide engagement gifts which were commonly made of gold, not a diamond engagement ring, to his future bride as shown in the term Sinsod ${ }^{8}$ Thongmun' ${ }^{9}$. Evidence of this

\footnotetext{
${ }^{8}$ Sinsod refers to bride's price or dowry in which a groom has to provide compensation to a bride's parents in order to recompense the loss of their daughter. However, sinsod is not part of western wedding culture.
} 
claim is a gold bracelet given by King Chulalongkorn, the fifth king of the Chakri Dynasty, to M.R. Sadab Ladawan who was the king's favorite concubine on April $1^{\text {st }}, 1906$. Instead of providing a diamond ring, the gold bracelet was used to symbolize King Rama V's affection for M.R. Sadab on the first day she became the lady-in-waiting to the king when she was sixteen years old. Therefore, it could be said that diamond rings became an element of weddings in Thailand after the reign of King Rama V. The diamond engagement ring is thus part of the mediated construction of weddings in Thai wedding magazines as well as the double-ring ceremony as I shall explain below.

\section{The Double-Ring Ceremony}

Another created western tradition in Thai wedding magazines is that of the doublering ceremony. After World War II, the groom's ring, according to Howard (2003: 837), signified male power in terms of providing support for his family. Additionally, Howard (2003: 837) indicates that this convention led to the alteration of religious lawmaking with regard to the blessing of the rings. That is to say, the wording of the ring blessing in the singular had to be shifted to the plural. However, the double-ring ceremony in Thai wedding magazines is different from the invented tradition in western culture in the matter of process, since the blessing of the rings is not included in the wedding ceremony. Brides

${ }^{9}$ Thongmun literally means gold engagement and can be compared to giving an engagement ring to the future bride. and grooms only exchange their rings with each other. Interestingly, these grooms' and brides' rings are constructed as symbols of love and togetherness since they are usually displayed close together as shown in Image 3 and Image 4.

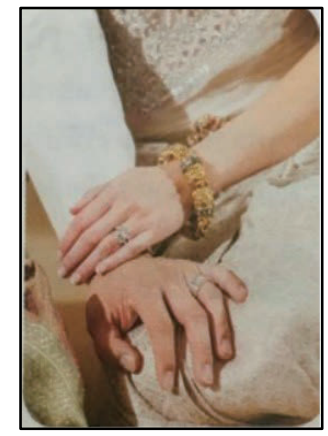

Image 3: The double-ring ceremony ( $\underline{\text { We}}$, February 2015, p. 67) Source: author's photograph.

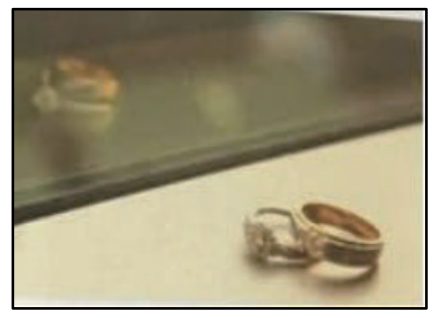

Image 4: Wedding rings for a bride and a groom (Love Wedding Magazine, February-April 2015, p. 119) Source: author's photograph.

\section{The White Wedding Gown}

Daniels (2012: 88) states that before 1840, red and other bright colors were considered customary for weddings in western countries. This convention was changed when Queen Victoria wore a white gown on the day of her wedding to Albert of Saxe. 
Interestingly, there were no red or brightcolored wedding gowns included in the data.

In the mid-1800s, the white wedding gown, according to Penner (2004: 2), was a sign of a perfect wedding, and the notion was stimulated by commercialization. Both brides and their bridesmaids were dressed in white. Penner (2004: 20) claims that the white gown at that time signified class, style, and wealth, not necessarily virtue. However, the color white in Thai culture is associated with a woman's purity and virginity. By presenting only brides in white wedding gowns, not any other colors, Thai wedding magazines construct the meaning of a bride as a virgin and assign this meaning to the color white of a wedding gown.

Moreover, the white wedding gowns in Thai wedding magazines symbolize western splendour since the white, western-style bridal gowns of the Victorian period, according to Penner (2004: 20), were connected to status and prosperity. White wedding gowns were displayed in every wedding story in my sample as shown in Image 5 .

\section{The Themes of Wedding Receptions}

My wedding theme selection in Thai wedding magazines was guided by my data and the dominant titles that featured in the headings of wedding stories. The themes of wedding receptions illustrated explicit forms of westernization in Thai weddings. Examples include: 'A Night of Fairytale'
(Wedding Guru, March-April, 2015, p. 46)

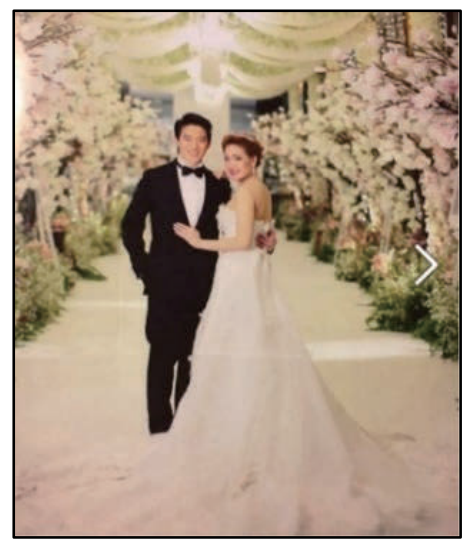

Image 5: The white wedding gown (Wedding Guru, March-April 2015, p. 43)

Source: author's photograph.

and 'Wedding in Wonderland' ( $\underline{W e}$, January 2015, p 54). These weddings are fairytal e weddings influenced by Western tradition in particular since the proliferation of magnificent weddings all over the world, as affirmed by Otnes and Pleck (2003: 62), is partially owing to wedding magazines and wedding films from the West. This is also the case in Thailand where weddings are more likely to be western. It is evidenced by the fairytale weddings in Thai wedding magazines that were presented in lavish settings with fairy tale decorations such as a princess wedding dress, a princess tiara, fairy bridesmaids, and a Cinderella pumpkin carriage decoration as shown in Image 6 and Image 7. 


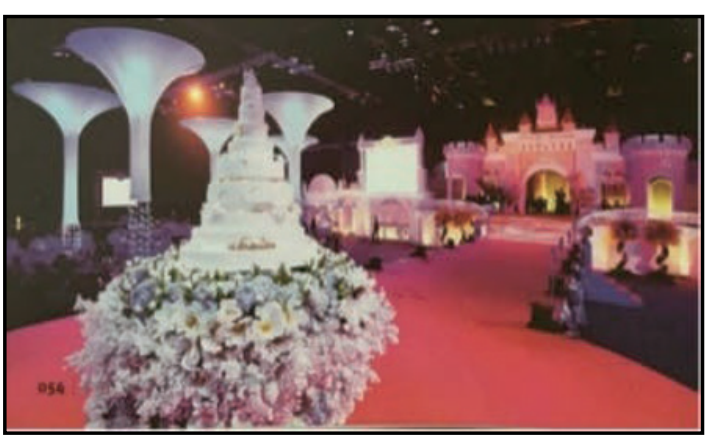

Image 6: A lavish fairytale setting ( $\underline{W e}$, January 2015, p. 54)

Source: author's photograph.

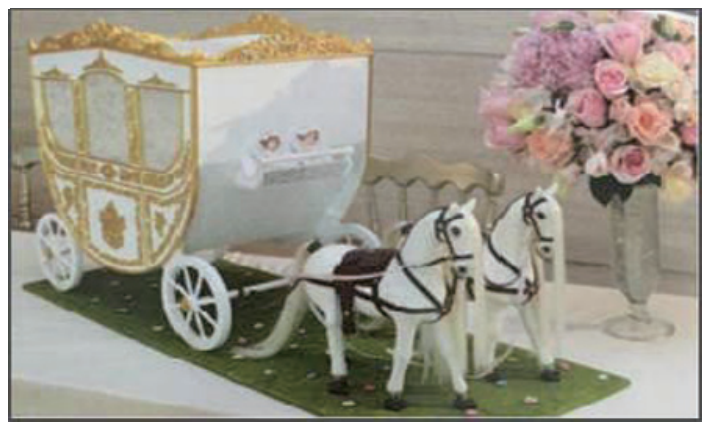

Image 7: A horse and carriage decoration (Wedding Guru, March-April 2015, p. 44)

Source: author's photograph.

Otnes and Pleck (2003:3) point out that lavish weddings or fairytale weddings can be regarded as wasteful affairs in terms of planning time and money; however, they are many women's dream weddings. On one hand, fairy tales are representative of happiness since they always have 'a happy ending': '.. and they lived happily ever after'. On the other hand, having a fairytale wedding implies the bride's status as a princess who is superior to other 'ordinary' women. This wedding format is thus a concrete way to display the bride's perfect happy life, as Clarke (2005: 350) claims that "the magic invoked by a performative spectacle and symbolic objects becomes a key means of generating a rite of passage through a public display of success". The fairytale wedding, in this sense, reinforces a couple's perfect life in terms of financial prosperity and social status since the fairytale wedding is the dream that cannot become true without financial support.

\section{The Construction of Women in Weddings in Thai Wedding Magazines}

Theories of the social construction of gender, according to Alsop et al (2002: 65), can be divided into two categories: materialist and discursive theories. Materialist theories focus on a social structure in which women and men are positioned within society and social relations of family, work, sexuality, etc. are concrete. Discursive theories emphasize the meaning of being male or female as produced by language and culture (Alsop et al, 2002: 65). Since I focus on constructions of women in wedding magazines, my emphasis is on the discursive dimensions of femininity. I examine the notions of what it means to be a woman as a bride, and what is valued about contemporary femininity in Thai culture, as expressed in the magazines I analyzed.

Holland (2004:8) suggests that there are a variety of accounts of what femininity is and how is it 'done': for example, femininity has been seen variously as a normative order, that is, a set of psychological traits (such as that women are considered to be more nurturing and less aggressive than men and have fewer spatial skills); a performance; 
and a process of interaction. In this research I see 'femininity' as the social construction of femaleness that is the result of (textually) mediated discourses. In examining contemporary ideas of femininity in magazines, I analyze femininity as it is presented in certain texts. I focus on what is valued about contemporary femininity and how the feminine might be constructed in wedding magazines. In this, cultural context plays a role. "What it means to be a 'woman' or a 'man' varies according to other differentiating features of positionality, historical time, class, ethnicity and bodily abilities" (Alsop et al, 2002: 81).

Friedan (1963: 32) challenged the conventional femininity portrayed in women's magazines - the idea that being a housewife and mother fulfilled a woman's life. The construction of women in Thai wedding magazines follows the conventional notion of femininity, in which women's lives are fulfilled by becoming a bride and getting married. The route of becoming a bride, in Thai culture, is begun by getting married.

It is noticeable that in Thai wedding magazines women are constructed as happy brides and prestige princesses. A bride obtains public recognition and honor as a princess as shown in the following examples. 'You are a Princess' ( $\underline{W e}$, April 2015 , p. 52) and 'Princess in Love' ( $\underline{W e}$, January 2015, p. 58). This high status depends on the wedding: a woman can become a 'temporary' princess during her wedding ceremony. In other words, the woman is considered a princess at her wedding. This construction also highlights the importance of being a bride since it provides a woman power and supremacy as stated obviously in the titles of stories below: 'She is the Owner of My Heart' ( $\underline{W e}$, December 2014, p. 48), 'She is the One' (We, November 2014, p. 58), and 'If I Remarry, It must be her' ( $\underline{W e}$, April 2015, p. $54)$. On one hand, the bride's influence on the wedding ceremony is based on her significance to the groom. In other words, the bride is important and that is why the wedding takes place. On the other hand, this underlines the inferiority of women to men, since gaining such power and significance is derived from men by means of getting married. However, images of women in contemporary wedding magazines may not be different from the past because the women are still considered inferior and subservient to men.

The reconstitution of femininity in contemporary Thai wedding magazines precisely involves the interplay of modern choices and social expectations. Ideal femininity in Thai wedding magazines is constructed in order to indulge the male gaze. Conventional femininity focuses on the 'ideal' beauty standard for women: slim bodies, fewer wrinkles, lighter skin, and wearing makeup. The ideal feminine beauty is constructed as a means to achieve the perfect wedding. Evidence of this claim is demonstrated in the images of Thai brides in the magazines, which only present goodlooking women as brides.

Furthermore, wedding stories in Thai wedding magazines reveal the mediated construction of being a bride. The magazines used in this study form a typical femininity centered on prosperous middle class women through a fantasy of luxurious weddings. 
There is an obvious class element displayed in the magazines based on the diamond jewelry and wedding decorations, which signify elegance and lavishness. Image 8 is one of the most explicit examples of the couple's economic status.

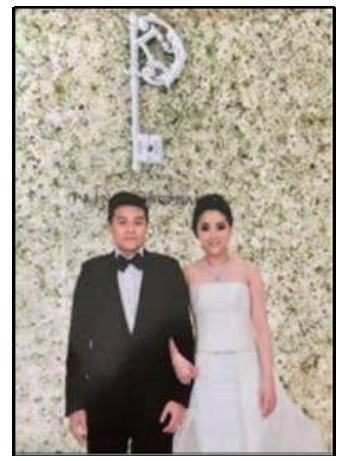

Image 8: A bride wearing diamond jewelry: a necklace, a bracelet, a ring, and earrings in front of a luxurious and ornate wedding backdrop (Wedding Guru, January February 2015, p. 89) Source: author's photograph.

The symbolic value of objects, especially diamonds, was presented in all the wedding stories in my sample. A diamond is regarded as the expression of eternal love and privileged economic status because of its strength and price, respectively. The high price of diamond jewelry is the main economic indicator that distinguishes women from a low social class. These 'ordinary' women thus can be classified as bourgeois according to their economic status.

Moreover, the ideology and construction of Thai women in these magazines are related to the economic status of the target readers as evidenced by the prices of the magazines. $\underline{\text { We }}$ and Wedding Guru cost 120 baht per issue whereas Love Wedding Magazine costs 150 baht per issue. This suggests that the magazines target female middle-class readers who earn a reasonable income.

\section{Conclusion}

The wedding stories in Thai wedding magazines may be dealt with on two levels: narrative content and the depiction of weddings and brides within the narratives. The meaning of 'wedding', according to Thai wedding magazines, is largely heteronormative and conventional, consisting of oppositesex newlywed couples.

With regard to the portrayal of weddings, Thai wedding magazines display weddings as sources of happiness in women's lives. The ideology of femininity reflected in the content of wedding stories highlights romantic relationships as key goals in women's lives.

By representing particular mediated images of brides as happy women and prestige princesses, weddings are constructed as the ultimate fulfilment of women's lives. As Belk et al. (2003: 347) state, "Despite the jading that occurs in a culture of abundance, we are still enchanted and desire to be enchanted... consumer desires entail hope and are vitally energizing and, conversely, can result in despair for those who cannot afford their fantasies". The wedding is thus a signifier of achievement in love. 
The wedding magazines connect women and their weddings with representations of class and style. The most common weddings were held in luxurious hotels with approximately three hundred to one thousand guests in attendance. Weddings, in this sense, are indicators of couples' economic status and social class. That is to say, wedding ceremonies in Thai wedding magazines are signs of grooms' ability to pay, as well as symbols of their love for their brides.

These lavish weddings emphasize women's inferior status to men, since the women's surnames are changed more often than the men's through marriage. On one hand, the magazines reinforce traditional women's roles within the domestic sphere as wives. On the other hand, the wedding magazines indicate the traditional patriarchal ideology that a woman's success depends on the man she is married to.

The construction of weddings and women involves a traditional gender ideology about the family and westernization. The weddings and women are a mediated construction of Thai wedding magazines and a reflection of contemporary Thai wedding culture.

\section{References}

Alsop, Rachel, Fitzsimons, Annette, and Lennon, Kathleen. 2002. Theorising Gender, Cambridge: Polity.

Anderson, Margaret L. 2006. Gender and Language: Theory and Practice.

London: Hodder Education.
Bain and Company. 2011. The Global Diamond Industry: Lifting the Veil of Mystery. Belgium: Antwerp World Diamond Centre (AWDC).

Barash, Susan Shapiro. 2012. The Nine Phases of Marriage: How to Make It, Break It, Keep It. New York: St. Martin's Press.

Barthes. R. 1986. The Responsibility of Forms: Critical Essays on Music, Art, and Representation. Oxford, Basil Blackwell.

Belk, R. W., Ger, G., and Askegaard, S.2003. The Fire of Desire: A Multisided Inquiry into Consumer Passion. Journal of Consumer Research 30: 326-350.

Brinig, M. F. 1990. Rings and Promises. Journal of Law, Economics, \& Organization 6: 203-215.

Clarke, A. 2005. The Globalization of Feminine Consumption. Current Anthropology 46. 349-351.

Daniels, Maggie and Carrie, Loveless. 2007. Wedding Planning and Management: Consultancy for Diverse Clients. Oxford: Elsevier.

Daniels, Maggie and Carrie, Loveless. 2012. Wedding Planning and Management. London: Routledge.

Friedan, Betty. 1963. The Feminine Mystique. Harmondsworth: Penguin. 
Guiren, Yuan. 2006. 'On Value and Culture', Frontiers of Philosophy in China 1(2): 237-244.

Holland, Samantha. 2004. Alternative Femininity: Body, Age and Identity. Oxford: Berg.

Howard, Vicki. 2003. A “Real Man's” Ring: Gender and Invention of Tradition. Journal of Social History 36: 837-857.

Humm, Maggie. 1995. The Dictionary of Feminist Theory. $2^{\text {nd }}$ edition. London: Prentice Hall.

Kunz, George Frederick. 2011. Rings for the Fingers. New York: Dover Publications, INC.

McRobbie, Angela. 1997. Back to Reality? Social Experience and Cultural Studies. Manchester: Manchester University Press.

Otnes, Cele C. and Pleck Elizabeth. 2003. Cinderella Dreams: The Allure of the Lavish Wedding (Life Passages). Los Angeles: University of California Press.

Penner, B. 2004. "A Vision of Love and Luxury": The Commercialization of Nineteenth-century American Weddings. Winterthur Portfolio 39: 120.

Reese, Stephen D., Gandy, Oscar H., and Grant, August E. 2001. Framing Public
Life: Perspectives on Media and Our Understanding of the Social World. Mahwah, NJ: Lawrence Erlbaum Associates.

Rokeach, M. 1971. The Measurement of Values and Value Systems. In G. Abcarian \& J. W. Soule (Eds.), Social Psychology and Political Behavior. Columbus, $\mathrm{OH}$ : Charles Merrill.

Soanes, Catherine. 2010. The Oxford English Dictionary. Oxford: Oxford University Press.

Tankard, J. W. 2001. "The Empirical Approach to the Study of Media Framing" in Framing Public Life: Perspectives on Media and Our Understanding of the Social World edited by Reese, Stephen D., Gandy, Oscar H., and Grant, August E. pp. 95 - 106. Mahwah, NJ: Lawrence Erlbaum Associates. 